\title{
Structures, Chemical Conversions, and Cytotoxicity of Tricholopardins C and D, Two Tricholoma Triterpenoids from the Wild Mushroom Tricholoma pardinum
}

\author{
Chen Shi ${ }^{1}$ Yue-Ling Peng ${ }^{2} \cdot$ Juan $\mathrm{He}^{1} \cdot$ Zheng-Hui Li $^{1} \cdot$ Ji-Kai Liu $^{1} \cdot$ Tao Feng $^{1}$ (i)
}

Received: 20 December 2020 / Accepted: 5 January 2021 / Published online: 15 January 2021

(C) The Author(s) 2021

\begin{abstract}
Two undescribed Tricholoma triterpenoids, namely tricholopardins C (1) and D (2), were isolated from the wild mushroom Tricholoma pardinum. Their structures with absolute configurations were elucidated by spectroscopic methods, as well as the single crystal X-ray diffraction. Compounds $\mathbf{1}$ and $\mathbf{2}$ were further obtained by chemical conversions from the known analogues. Compound $\mathbf{1}$ showed significant cytotoxicity to MCF-7 and Hela cell lines with $\mathrm{IC}_{50}$ values of $4.7 \mu \mathrm{M}$ and $9.7 \mu \mathrm{M}$, respectively. Its mechanism of inducing MCF-7 cell apoptosis was studied briefly.
\end{abstract}

\section{Graphical Abstract}

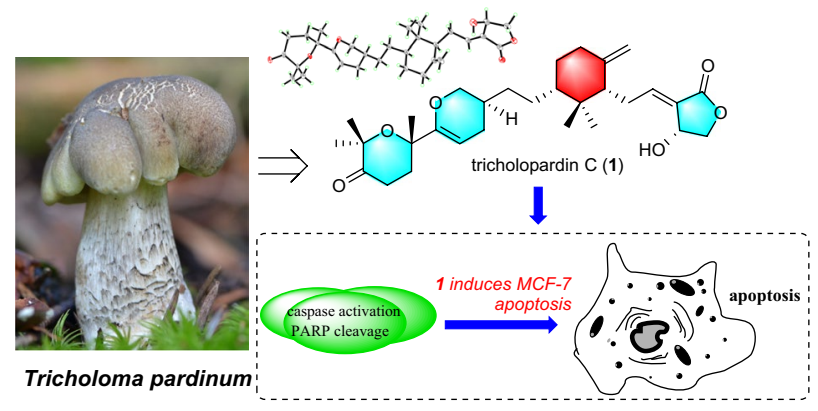

Keywords Tricholoma pardinum · Tricholoma triterpenoids · Chemical conversion · Cytotoxicity

\section{Introduction}

Cancer represents one of the most threats to human health, accounting for $13 \%$ of all deaths worldwide according to the World Health Organization [1]. Although a great number of

Chen Shi, Yue-Ling Peng and Juan He are authors contributed equally to the work.

Tao Feng

tfeng@mail.scuec.edu.cn

1 School of Pharmaceutical Sciences, South-Central University for Nationalities, Wuhan 430074,

People's Republic of China

2 The Third People's Hospital of Datong, Datong 037000, People's Republic of China chemotherapeutic drugs are available over the counter, the cancer cure rate is really difficult to be improved effectively [2]. Natural products remain an important resource for the identification of novel therapeutic leads and provide avenues for the discovery of new molecular targets [3], while fungal metabolites with a variety of chemical structures and diverse biological activities play an important role in drug discovery [4].

Tricholoma triterpenoids (TTs) are a class of special natural products featuring a central methylenecyclohexane ring linked to a $\gamma$-lactone substituent and a pyrane ring shared a spiroketal carbon with the bridged heterocyclic system [5, 6]. So far, TTs have been found in a very narrow distribution limited to several mushrooms of the genus Tricholoma (Tricholomataceae), such as saponaceolides A-G $[6,7]$ and 
T [8] from T. saponaceum, trichomycins A and B from a new species Tricholoma sp. AU1 [9], saponaceolides H-S [10, 11] and terreolides A-F [10] from T. terreum, and tricholopardins A and B from T. pardinum [5]. Previous studies have demonstrated that TTs have promising cytotoxicity and anti-inflammatory effects. Saponaceolides A and B were found to inhibit the growth of a human colon adenocarcinoma cell line (line LoVo) with $\mathrm{ID}_{50}$ values of $450 \mathrm{ng} / \mathrm{mL}$ and $163 \mathrm{ng} / \mathrm{mL}$, respectively [6, 7] while saponaceolide Q showed cytotoxicity to four human cancer cell lines [11]. In addition, tricholopardin A potently inhibited nitric oxide production in lipopolysaccharide-induced RAW264.7 macrophages with an $\mathrm{IC}_{50}$ of $0.08 \mu \mathrm{M}$ [5]. All the information suggested that TTs have a good research prospect. As our continuous search for new and bioactive metabolites from Tricholoma mushrooms [5, 10, 14], a further chemical investigation on the mushroom T. pardinum was undertaken. As a result, two novel TTs namely tricholopardins $\mathrm{C}(\mathbf{1})$ and $\mathrm{D}(\mathbf{2})$ were obtained (Fig. 1). Their structures were established by means of spectroscopic methods. Their absolute configurations were determined by the single crystal X-ray diffraction, as well as the chemical conversions from the known analogues. Both two compounds possessed a novel linear structure involving four independent rings. Compounds 1 and $\mathbf{2}$ were evaluated for their cytotoxicity against human breast adenocarcinoma cell line (MCF-7) and human cervical carcinoma cell lines (Hela). The mechanism of 1 inducing MCF-7 cell apoptosis was also investigated.

\section{Results and Discussion}

A sample of air-dried fruiting bodies of T. pardinum $(1.5 \mathrm{~kg})$ was extracted using $\mathrm{MeOH}$ and partitioned using EtOAc to give an EtOAc extract (56 g). The latter was separated through column chromatography to afford $\mathbf{1}(1.2 \mathrm{mg})$ and $\mathbf{2}$ $(2.6 \mathrm{mg})$. More samples of $\mathbf{1}(3.5 \mathrm{mg})$ and $\mathbf{2}(2.1 \mathrm{mg})$ were prepared by chemical conversion from saponaceolides A and $\mathrm{B}$, respectively.

Tricholopardin C (1) was isolated as colorless crystals. Its molecular formula $\mathrm{C}_{30} \mathrm{H}_{44} \mathrm{O}_{6}$ was identified by HRESIMS data, corresponding to nine degrees of unsaturation. IR

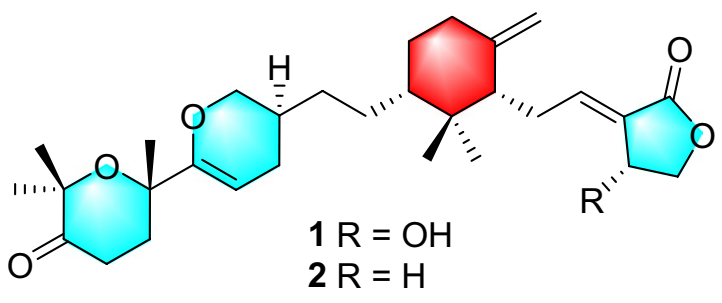

Fig. 1 Structures of compounds 1 and 2 absorption bands at $3432 \mathrm{~cm}^{-1}$ and $1736 \mathrm{~cm}^{-1}$ revealed $\mathrm{OH}$ and $\mathrm{C}=\mathrm{O}$ functional groups. In the ${ }^{1} \mathrm{H}$ NMR spectrum, five singlets for methyl groups were readily identified. In addition, four olefinic protons including two singlets at $\delta_{\mathrm{H}} 4.90$ and 4.58 assigned for a terminal double bond were detected. The ${ }^{13} \mathrm{C}$ NMR spectrum revealed thirty carbon resonances, which were assigned by DEPT and HSQC spectra into five $\mathrm{CH}_{3}$, eleven $\mathrm{CH}_{2}$, six $\mathrm{CH}$, and eight $\mathrm{C}$ (Table 1). Preliminary analysis of these data, as well as the 2D NMR data (Fig. 2), suggested that 1 should be a TTs derivative. The existence of a central cyclohexane ring $A$ linked to a $\gamma$-lactone $B$, identical to that of saponaceolide $A$, was established by comparison with data of saponaceolide A (Fig. 2). Analysis of ${ }^{1} \mathrm{H}-{ }^{1} \mathrm{H}$ COSY data revealed a linkage of starting from an olefinic carbon C-22 to C-23, C-24, and C-30. In association with the key HMBC correlations from $\delta_{\mathrm{H}} 4.01(1 \mathrm{H}, \mathrm{m}, \mathrm{H}-30 \mathrm{a})$ and $3.54(1 \mathrm{H}, \mathrm{dd}, J=10.0,8.8 \mathrm{~Hz}, \mathrm{H}-30 \mathrm{~b})$ to $\delta_{\mathrm{C}} 156.2$ (s, C-21), a dihydropyran $C$ was established. It was connected to ring $A$ by two methylene carbons $\left(\mathrm{CH}_{2}-25\right.$ and $\left.\mathrm{CH}_{2}-26\right)$ as established by the ${ }^{1} \mathrm{H}-{ }^{1} \mathrm{H}$ COSY and $\mathrm{HMBC}$ data. In the HMBC spectrum, a methyl signal at $\delta_{\mathrm{H}} 1.40\left(3 \mathrm{H}, \mathrm{s}, \mathrm{H}_{3}-29\right)$ showed three correlations to $\delta_{\mathrm{C}} 74.5$ (s, C-20), 30.0 (t, C-19), and $\mathrm{C}-21$, while the other two methyl signals at $\delta_{\mathrm{H}} 1.34(3 \mathrm{H}, \mathrm{s}$, $\left.\mathrm{H}_{3}-28\right)$ and $1.36\left(3 \mathrm{H}, \mathrm{s}, \mathrm{H}_{3}-27\right)$ showed key correlations to $\delta_{\mathrm{C}}$ 80.3 (s, C-16) and 214.6 (s, C-17). The information, as well as the MS data, suggested that the remaining eight carbons constructed a tetrahydropyran $D$ involving the substituents of two methyls at C-16, one carbonyl carbon at $\mathrm{C}-17$, and one methyl at C-20. Therefore, the planar structure of $\mathbf{1}$ was elucidated as shown.

In the ROESY spectrum, one cross peak of $\mathrm{H}-10 / \mathrm{H}-7$ indicated the double bond between C-8 and C-9 to be transform, while a cross peak of $\mathrm{H}-2 / \mathrm{H}-6$ indicated that $\mathrm{H}-2$ and H-6 were on the same face (Fig. 2). However, the stereochemistry of C-20 and C-24 could not be elucidated by the ROESY data. The chemical conversion of $\mathbf{1}$ was achieved from saponaceolide A (Scheme 1), obtained from the same source [1], whose absolute configuration has been demonstrated previously $[2,8]$. This conversion suggested the stereo configurations of C-20 and C-24 to be $S$. In addition, based on the sample accumulation by the chemical conversion, a single crystal for $\mathbf{1}$ was obtained from a mixture of methanol/ $\mathrm{H}_{2} \mathrm{O}(20 / 1$, v/v) after attempts, and the single crystal X-ray diffraction for $\mathbf{1}$ not only confirmed the planar structure as established by the spectroscopic methods but also determined the absolute configuration by the Flack parameter of -0.01(10) (CCDC: 1,907,789) (Fig. 3).

Tricholopardin D (2) was isolated as a colorless oil. The molecular formula $\mathrm{C}_{30} \mathrm{H}_{44} \mathrm{O}_{5}$ was revealed by the HRESIMS data, 16 mass units less than that of $\mathbf{1}$. All the ${ }^{1} \mathrm{H}$ and ${ }^{13} \mathrm{C}$ NMR data (Table 1) indicated that $\mathbf{2}$ had a similar structure to that of $\mathbf{1}$, except that the hydroxy at C-10 in $\mathbf{1}$ was reduced into methylene $\left(\delta_{\mathrm{C}} 25.3 ; \delta_{\mathrm{H}} 2.88\right)$ in 2 , as supported by the 
Table $1{ }^{1} \mathrm{H}(600 \mathrm{MHz})$ and ${ }^{13} \mathrm{C}(150 \mathrm{MHz})$ NMR data for $\mathbf{1}$ (methanol- $\left.d_{4}\right)$

\begin{tabular}{|c|c|c|c|c|}
\hline \multirow[t]{2}{*}{ No } & \multicolumn{2}{|l|}{1} & \multicolumn{2}{|l|}{2} \\
\hline & $\delta_{\mathrm{H}}$ & $\delta_{\mathrm{C}}$ & $\delta_{\mathrm{H}}$ & $\delta_{\mathrm{C}}$ \\
\hline 1 & & $39.8, \mathrm{C}$ & & 39.7, C \\
\hline 2 & $1.15, \mathrm{~m}$ & $48.1, \mathrm{CH}$ & $1.14, \mathrm{~m}$ & $48.2, \mathrm{CH}$ \\
\hline $3 \mathrm{a}$ & $1.81, \mathrm{~m}$ & $30.1, \mathrm{CH}_{2}$ & $1.80, \mathrm{~m}$ & $30.2, \mathrm{CH}_{2}$ \\
\hline $3 b$ & $1.14, \mathrm{~m}$ & & $1.13, \mathrm{~m}$ & \\
\hline $4 a$ & $2.33, \mathrm{~m}$ & 37.0, $\mathrm{CH}_{2}$ & $2.31, \mathrm{~m}$ & 37.3, $\mathrm{CH}_{2}$ \\
\hline $4 b$ & $1.95, \mathrm{~m}$ & & $1.94, \mathrm{~m}$ & \\
\hline 5 & & 148.0, C & & $148.1, \mathrm{C}$ \\
\hline 6 & $1.92, \mathrm{~m}$ & $53.6, \mathrm{CH}$ & $1.93, \mathrm{~m}$ & $53.5, \mathrm{CH}$ \\
\hline $7 \mathrm{a}$ & $2.61, \mathrm{~m}$ & $26.2, \mathrm{CH}_{2}$ & $2.41, \mathrm{~m}$ & 26.9, $\mathrm{CH}_{2}$ \\
\hline $7 b$ & & & $2.28, \mathrm{~m}$ & \\
\hline 8 & $6.99, \mathrm{t}(6.9)$ & $149.5, \mathrm{CH}$ & $6.72, \mathrm{t}(6.8)$ & $142.3, \mathrm{CH}$ \\
\hline 9 & & 127.9, C & & 124.6, C \\
\hline 10 & $5.05, \mathrm{~m}$ & $66.3, \mathrm{CH}$ & $2.88, \mathrm{~m}$ & $25.3, \mathrm{CH}_{2}$ \\
\hline $11 \mathrm{a}$ & $4.44, \mathrm{dd}(10.4,6.0)$ & $74.3, \mathrm{CH}_{2}$ & $4.37, \mathrm{t}(7.5)$ & $65.4, \mathrm{CH}_{2}$ \\
\hline $11 \mathrm{~b}$ & $4.26, \mathrm{dd}(10.4,1.8)$ & & & \\
\hline 12 & $0.61, \mathrm{~s}$ & $15.1, \mathrm{CH}_{3}$ & $0.58, \mathrm{~s}$ & $14.9, \mathrm{CH}_{3}$ \\
\hline 13 & $1.03, \mathrm{~s}$ & $26.7, \mathrm{CH}_{3}$ & $1.02, \mathrm{~s}$ & 26.6, $\mathrm{CH}_{3}$ \\
\hline $14 \mathrm{a}$ & $4.90, \mathrm{~s}$ & $108.3, \mathrm{CH}_{2}$ & $4.84, \mathrm{~s}$ & 107.7, $\mathrm{CH}_{2}$ \\
\hline $14 b$ & $4.58, \mathrm{~s}$ & & $4.40, \mathrm{~s}$ & \\
\hline 15 & & $169.9, \mathrm{C}$ & & $171.5, \mathrm{C}$ \\
\hline 16 & & $80.3, \mathrm{C}$ & & $80.3, \mathrm{C}$ \\
\hline 17 & & 214.6, C & & 214.6, C \\
\hline 18 & $2.43, \mathrm{~m}$ & $33.3, \mathrm{CH}_{2}$ & $2.43, \mathrm{~m}$ & $33.3, \mathrm{CH}_{2}$ \\
\hline $19 \mathrm{a}$ & $2.28, \mathrm{~m}$ & $30.0, \mathrm{CH}_{2}$ & $2.28, \mathrm{~m}$ & $30.0, \mathrm{CH}_{2}$ \\
\hline $19 b$ & $1.99, \mathrm{~m}$ & & $2.04, \mathrm{~m}$ & \\
\hline 20 & & $74.5, \mathrm{C}$ & & 74.5, C \\
\hline 21 & & $156.2, \mathrm{C}$ & & $156.2, \mathrm{C}$ \\
\hline 22 & $4.93, \mathrm{dd}(4.3,3.0)$ & $94.9, \mathrm{CH}$ & $4.93, \mathrm{dd}(4.4,3.0)$ & $94.9, \mathrm{CH}$ \\
\hline $23 \mathrm{a}$ & $2.17, \mathrm{~m}$ & $27.3, \mathrm{CH}_{2}$ & $2.17, \mathrm{~m}$ & 27.3, $\mathrm{CH}_{2}$ \\
\hline $23 b$ & $1.68, \mathrm{~m}$ & & $1.68, \mathrm{~m}$ & \\
\hline 24 & $1.75, \mathrm{~m}$ & $32.5, \mathrm{CH}$ & $1.74, \mathrm{~m}$ & $32.5, \mathrm{CH}$ \\
\hline $25 \mathrm{a}$ & $1.40, \mathrm{~m}$ & $31.2, \mathrm{CH}_{2}$ & $1.40, \mathrm{~m}$ & $31.2, \mathrm{CH}_{2}$ \\
\hline $25 b$ & $1.10, \mathrm{~m}$ & & $1.10, \mathrm{~m}$ & \\
\hline $26 \mathrm{a}$ & $1.59, \mathrm{~m}$ & $28.0, \mathrm{CH}_{2}$ & $1.59, \mathrm{~m}$ & $28.1, \mathrm{CH}_{2}$ \\
\hline $26 b$ & $0.93, \mathrm{~m}$ & & $0.92, \mathrm{~m}$ & \\
\hline 27 & $1.36, \mathrm{~s}$ & 27.9, $\mathrm{CH}_{3}$ & $1.36, \mathrm{~s}$ & $27.9, \mathrm{CH}_{3}$ \\
\hline 28 & $1.34, \mathrm{~s}$ & $26.2, \mathrm{CH}_{3}$ & $1.34, \mathrm{~s}$ & $26.2, \mathrm{CH}_{3}$ \\
\hline 29 & $1.40, \mathrm{~s}$ & $28.3, \mathrm{CH}_{3}$ & $1.40, \mathrm{~s}$ & $28.3, \mathrm{CH}_{3}$ \\
\hline $30 \mathrm{a}$ & $4.01, \mathrm{~m}$ & $70.3, \mathrm{CH}_{2}$ & $4.02, \mathrm{~m}$ & $70.3, \mathrm{CH}_{2}$ \\
\hline $30 \mathrm{~b}$ & $3.54, \mathrm{dd}(10.0,8.8)$ & & 3.54 , dd $(10.1,8.7)$ & \\
\hline
\end{tabular}

HMBC correlations from $\delta_{\mathrm{H}} 2.88(2 \mathrm{H}, \mathrm{m}, \mathrm{H}-10)$ to $\delta_{\mathrm{C}} 124.6$ (s, C-9) and 65.4 (t, C-11), and the ${ }^{1} \mathrm{H}-{ }^{1} \mathrm{H}$ COSY cross peak between $\mathrm{H}-10$ and $\mathrm{H}-11$. A product obtained by the chemical conversion from saponaceolide B showed NMR patterns identical to those of $\mathbf{2}$, elucidating the absolute configuration of $\mathbf{2}$ to be the same to that of $\mathbf{1}$ (Scheme 1).

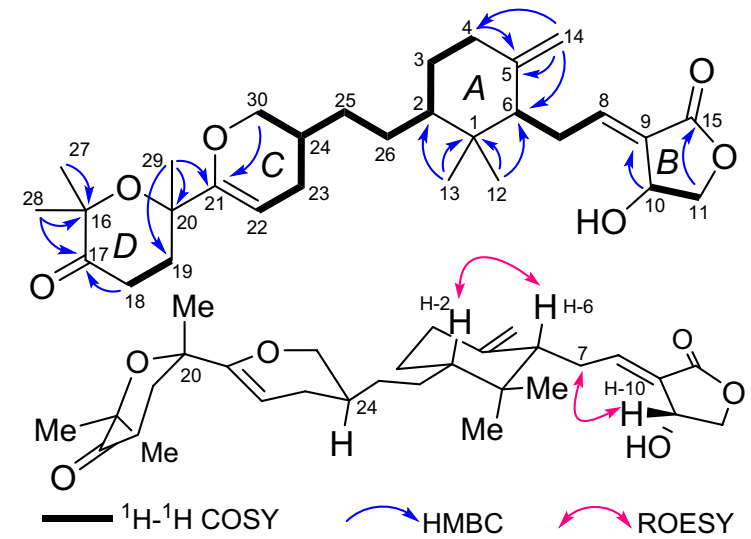

Fig. 2 Key 2D NMR correlations for $\mathbf{1}$

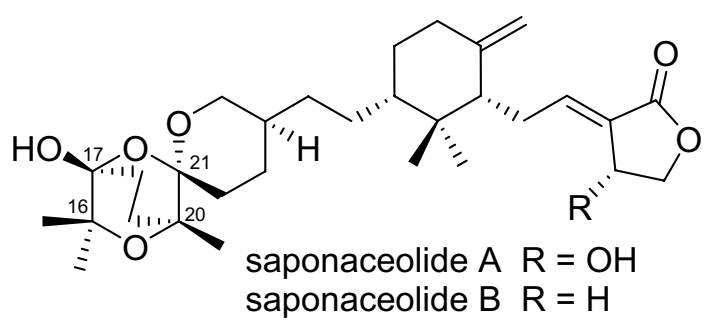

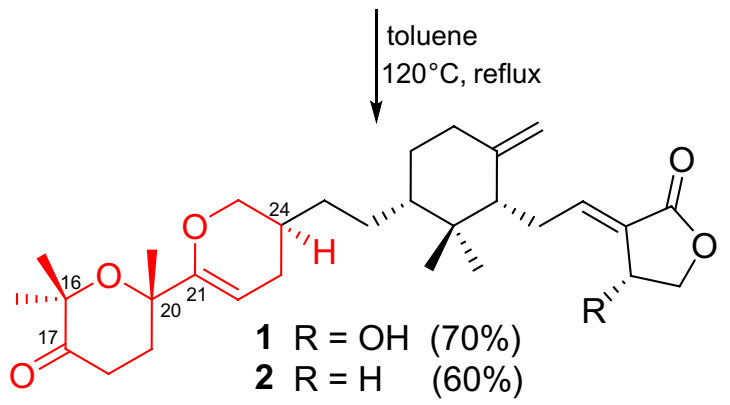

Scheme 1 Chemical conversions of $\mathbf{1}$ and $\mathbf{2}$

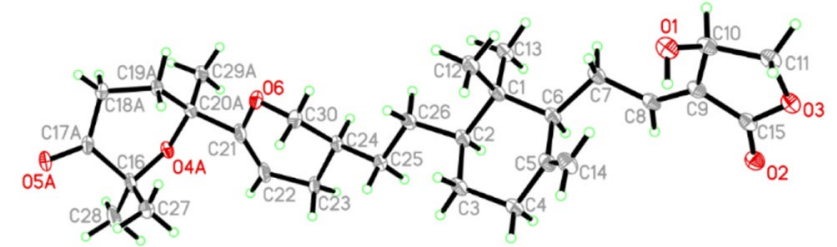

Fig. 3 ORTEP diagram of $\mathbf{1}$ showing absolute configuration

Compounds 1 and $\mathbf{2}$ were evaluated for their cytotoxicity to human MCF-7 and Hela cell lines. As a result, both of them possessed cytotoxic to two cell lines (Table 2). Significantly, compound 1 exhibited a strong inhibition on MCF-7 cell, with an $\mathrm{IC}_{50}$ value of $4.7 \mu \mathrm{M}$.

Induction of apoptosis is considered as a possible mechanism of most of the chemotherapeutic agents, and targeting 
Table 2 Cytotoxicity of $\mathbf{1}$ and $\mathbf{2}\left(\mathrm{IC}_{50}, \mu \mathrm{M}\right)$

\begin{tabular}{lcl}
\hline Compd & MCF-7 & Hela \\
\hline $\mathbf{1}$ & $4.7 \pm 0.10$ & $9.7 \pm 0.08$ \\
$\mathbf{2}$ & $13.9 \pm 0.17$ & $17.7 \pm 0.13$ \\
Taxol $^{\mathrm{a}}$ & $<0.008$ & $<0.008$ \\
\hline
\end{tabular}

apositive control

the apoptotic signaling system is becoming a promising strategy for the development of novel chemotherapeutic molecules [15]. In order to understand whether $\mathbf{1}$ inhibited cell growth through apoptosis, an annexin V/propidium iodide (PI) staining assay was used to detect the apoptotic rati [16]. As shown in Fig. 4, after treatment with $0 \mu \mathrm{M}, 1 \mu \mathrm{M}, 3 \mu \mathrm{M}$, and $5 \mu \mathrm{M}$ of 1 for $24 \mathrm{~h}$, the apoptosis rate increases gradually in a concentration-dependent manner. When drug concentration is $5 \mu \mathrm{M}$, the early apoptotic cells represent $19.51 \%$ of the total cells, which increases $11.48 \%$ than untreated cells. Meanwhile, the late apoptotic and necrotic cells represent $6.17 \%$ of the total cells, which increases $2.08 \%$ than untreated cells. (a) Control

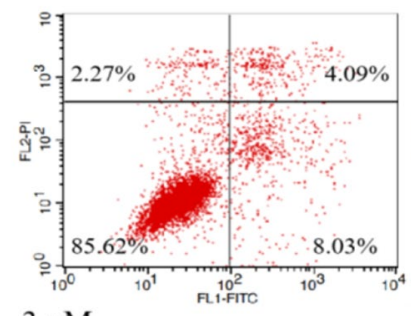

$3 \mu \mathrm{M}$

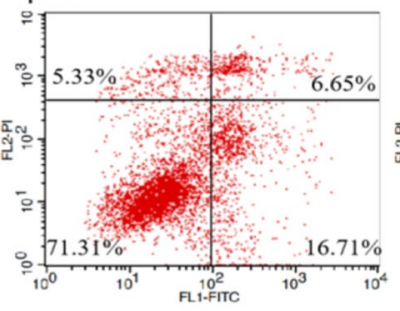

(b)

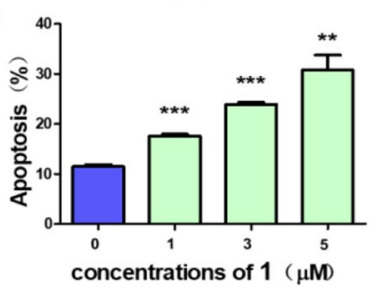

$1 \mu \mathrm{M}$

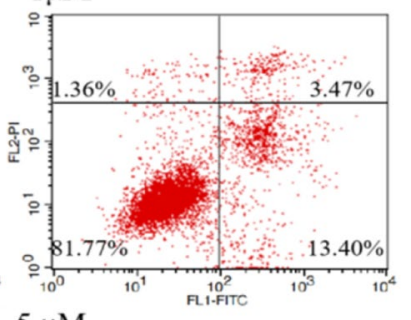

$5 \mu \mathrm{M}$

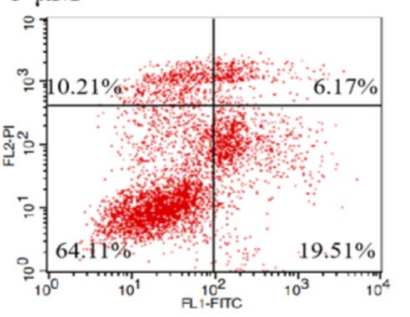

Fig. 4 Effect of 1 on apoptosis of MCF-7 cells. (a) Induction of apoptosis was measured by annexin V/PI double-staining assay after treated with various concentrations $(0 \mu \mathrm{M}, 1 \mu \mathrm{M}, 3 \mu \mathrm{M}, 5 \mu \mathrm{M})$ of $\mathbf{1}$ for $24 \mathrm{~h}$. (b) Apoptosis was expressed as a percentage of control. Data are presented as mean $\pm \mathrm{SD}$ of triplicates. $(* \mathrm{P}<0.05, * * \mathrm{P}<0.01$, $* * * \mathrm{P}<0.001$ compared with control, $\mathrm{n}=3$ )
Since the generation of cleaved poly-ADP-ribose polymerase (PARP) protein mediated by caspase family is considered as an important biomarker of apoptosis [17], the involvement of caspases in 1-induced apoptosis was further examined. As shown in Fig. 5, caspase-3 and caspase-9 were both activated by comparing with the control groups. Then, the cleaved caspase-3 activated the self-cleavage of PARP, which gave rise to apoptosis. These results revealed that $\mathbf{1}$ could induce tumor cell death by apoptosis.

\section{Conclusions}

In summary, two novel Tricholoma triterpenoids, namely tricholopardins C (1) and D (2), have been obtained from the fruiting bodies of the wild mushroom T. pardinum. The structures were unambiguously determined by analysis of their NMR and HRESIMS data, with the absolute configuration being confirmed by single-crystal X-ray diffraction.

(a)

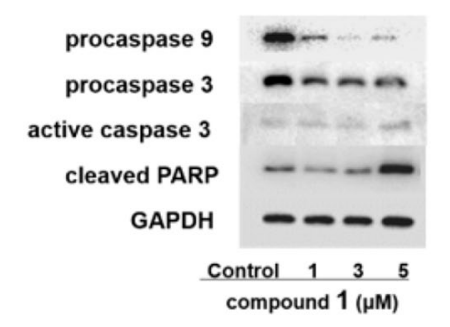

(b)
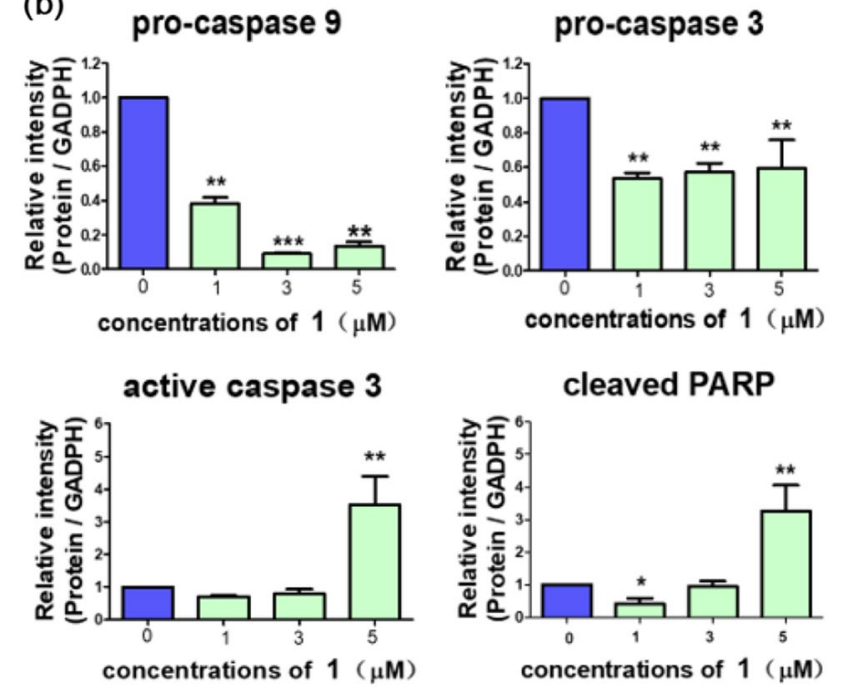

Fig. 5 Effect of 1 on apoptotic relating-protein of MCF-7 cells. (a) Expression of apoptosis-related proteins in MCF-7 cells treated with various concentrations $(0 \mu \mathrm{M}, 1 \mu \mathrm{M}, 3 \mu \mathrm{M}, 5 \mu \mathrm{M})$ of 1 for $24 \mathrm{~h}$. The levels of apoptotic proteins including caspase 3, caspase 9 , and cleaved-poly-ADP-ribose polymerase (cleaved-PARP) were assessed by Western Blot assay. (b) The densitometric analysis represents the relative ratios of respective proteins to GAPDH. Data are presented as mean \pm SD of triplicates. $(* \mathrm{P}<0.05, * * \mathrm{P}<0.01$, *** $\mathrm{P}<0.001 \mathrm{com}-$ pared with control, $n=3$ ) 
They possess a novel framework which was available by chemical conversions from saponaceolides A and B. The new modification of the isolated compound expand the chemical diversity of the Tricholoma triterpenoids family of natural products. Compound $\mathbf{1}$ exhibits significant cytotoxicity to MCF-7 by inducing apoptosis, presenting us with a great opportunity to discover promising natural agents for new antitumor drugs.

\section{Experimental Section}

\subsection{General Experimental Procedures}

Melting points were obtained on an X-4 micro melting point apparatus. Optical rotations were measured with a Horiba SEPA-300 polarimeter. IR spectra were obtained with a Tenor 27 spectrophotometer using $\mathrm{KBr}$ pellets. 1D and 2D spectra were run on a Bruker Avance III $600 \mathrm{MHz}$ spectrometer with TMS as an internal standard. Chemical shifts $(\delta)$ were expressed in ppm with reference to the solvent signals. Mass spectra were recorded on an Agilent 6200 Q-TOF MS system. Column chromatography (CC) was performed on silica gel (200-300 mesh, Qingdao Marine Chemical Ltd., Qingdao, People's Republic of China), RP-18 gel (20-45 $\mu \mathrm{m}$, Fuji Silysia Chemical Ltd., Japan), and Sephadex LH-20 (Pharmacia Fine Chemical Co., Ltd., Sweden). Medium Pressure Liquid Chromatography (MPLC) was performed on a Büchi Sepacore System equipping with pump manager C-615, pump modules C-605 and fraction collector C-660 (Büchi Labortechnik AG, Flawil, Switzerland), and columns packed with RP-18 gel. Preparative High Performance Liquid Chromatography (prep-HPLC) was performed on an Agilent 1260 liquid chromatography system equipped with Zorbax SB-C18 columns ( $5 \mu \mathrm{m}, 9.4 \mathrm{~mm} \times 150 \mathrm{~mm}$ or $21.2 \mathrm{~mm} \times 150 \mathrm{~mm}$ ) and a DAD detector. Fractions were monitored by TLC (GF 254, Qingdao Haiyang Chemical Co., Ltd. Qingdao), and spots were visualized by heating silica gel plates sprayed with $10 \% \mathrm{H}_{2} \mathrm{SO}_{4}$ in $\mathrm{EtOH}$.

\subsection{Fungi Material}

Wild mushrooms, Tricholoma pardinum, were collected from Schwarzwald in southwestern Germany in October 2014 and identified by Prof. Yu-Cheng Dai of Beijing Forestry University. A voucher specimen (No. HPCF20141008.6) was deposited at School of Pharmaceutical Sciences, South-Central University for Nationalities.

\subsection{Extract and Isolation}

The air-dried fruiting bodies of T. Pardinum $(1.5 \mathrm{~kg})$ were extracted with $\mathrm{MeOH}(24 \mathrm{~h} \times 3)$, and then partitioned with
$\mathrm{H}_{2} \mathrm{O}$ and EtOAc (1:1). Finally, an EtOAc extract (56 g) was obtained, which was submitted to silica gel $\mathrm{CC}$ using $\mathrm{CHCl}_{3}-\mathrm{MeOH}$ (from 1:0 to 0:1) to give eight fractions (A-H). Fraction D (2.3 g) was separated by silica gel CC using petroleum ether-acetone $(10: 1-4: 1, \mathrm{v} / \mathrm{v})$ to afford five sub-fractions (D1-D5). Fraction D4 (18 mg) was purified by HPLC (MeCN-H $\mathrm{H}_{2} \mathrm{O}$ from 80:20 to $\left.95: 5, \mathrm{v} / \mathrm{v}, 25 \mathrm{~min}\right)$ to afford compound $2(2.6 \mathrm{mg})$. Fraction $\mathrm{E}(4.8 \mathrm{mg})$ was separated by MPLC equipped with a RP-18 column eluted with $\mathrm{MeOH}-\mathrm{H}_{2} \mathrm{O}$ (from 60:40 to 90:10, v/v, $40 \mathrm{~min}$ ) to give sixsubfractions (E1-E6). Fraction E3 was purified by HPLC $\left(\mathrm{MeCN}-\mathrm{H}_{2} \mathrm{O}\right.$ from 70:30 to 90:10, v/v, $20 \mathrm{~min}$ ) to afford compound $\mathbf{1}(1.2 \mathrm{mg})$.

\subsection{Spectroscopic Data of Compounds}

\subsubsection{Tricholopardin C (1)}

Colorless crystals, mp $126-128{ }^{\circ} \mathrm{C} ;[\alpha]_{\mathrm{D}}^{25}+26.6$ (c 0.22 , $\mathrm{MeOH})$; IR $(\mathrm{KBr}) \nu_{\max }=3432,2931,1736,1631,1026$, 1191, $1017 \mathrm{~cm}^{-1}$; UV (MeOH): $\lambda_{\max }(\log \varepsilon): 225$ (3.33), 202 (3.79) nm; ${ }^{1} \mathrm{H}$ and ${ }^{13} \mathrm{C}$ NMR data, see Table 1; Positive ion HRESIMS $\mathrm{m} / \mathrm{z} 523.30298[\mathrm{M}+\mathrm{Na}]^{+}$(calcd for $\mathrm{C}_{30} \mathrm{H}_{44} \mathrm{O}_{6} \mathrm{Na}^{+}$, 523.30301).

\subsubsection{Tricholopardin D (2)}

Colorless oil; $[\alpha]_{\mathrm{D}}^{25}-10.8(\mathrm{c} 0.15, \mathrm{MeOH}) ; \mathrm{IR}(\mathrm{KBr})$ $\nu_{\max }=2930,1734,1631,1027,1192,1018 \mathrm{~cm}^{-1}$; UV (MeOH): $\lambda_{\max }(\log \varepsilon): 223$ (3.31), $201(3.82) \mathrm{nm} ;{ }^{1} \mathrm{H}$ and ${ }^{13} \mathrm{C}$ NMR data, see Table 1; Positive ion HRESIMS $\mathrm{m} / \mathrm{z}$ 507.30801 [M+Na] $]^{+}$(calcd for $\mathrm{C}_{30} \mathrm{H}_{44} \mathrm{O}_{5} \mathrm{Na}^{+}$, 507.30810).

\subsubsection{Crystal Data for Tricholopardin C (1)}

A light colorless Prism-like of $\mathrm{C}_{30} \mathrm{H}_{44} \mathrm{O}_{6}, M=500.65$, approximate dimensions $0.054 \mathrm{~mm} \times 0.232 \mathrm{~mm} \times 0.700 \mathrm{~mm}$, was used for the X-ray crystallographic analysis on the BRUKER D8 QUEST. The integration of the data using a monoclinic unit cell yielded a total of 34,067 reflections to a maximum $\theta$ angle of $79.39^{\circ}(0.78 \AA$ resolution $)$, of which 5674 were independent (average redundancy 6.004, completeness $\left.=99.5 \%, \mathrm{R}_{\text {int }}=6.77 \%, \mathrm{R}_{\text {sig }}=4.65 \%\right)$ and 5231 $(92.19 \%)$ were greater than $2 \sigma\left(\mathrm{F}^{2}\right)$. The final cell constants of $\underline{a}=8.3155(10) \AA, \underline{b}=6.1091(8) \AA, \underline{c}=26.765(3) \AA$, $\alpha=90.00^{\circ}, \beta=94.589(5)^{\circ}, \gamma=90.00^{\circ}, V=1355.3(3) \AA^{3}$, $\mathrm{T}=100$ (2) K. Data were corrected for absorption effects using the Multi-Scan method (SADABS). The structure was solved and refined using the Bruker SHELXTL Software Package, using the space group P 1211 , with $Z=2$. The final anisotropic full-matrix least-squares refinement on $\mathrm{F}^{2}$ with 397 variables converged at $\mathrm{R} 1=4.62 \%$, for the observed data and $w R 2=12.44 \%$ for all data. The goodness-of-fit was 
1.092. The absolute configuration was determined by the Flack parameter $=-0.01(10)$, which was determined using 2110 quotients [(I+)-(I-)]/[(I+)+(I-)]. CCDC: 1,907,789 (https://www.ccdc.cam.ac.uk).

\subsection{Chemical Conversations of 1 and 2}

Saponaceolides A (5 mg) and B (3.5 mg) were added to toluene and stirred at $200 \mathrm{rpm}$ for $12 \mathrm{~h}$ at $120{ }^{\circ} \mathrm{C}$, respectively. The two reactants were separated by HPLC to give compound $1(3.5 \mathrm{mg}$, yield $=70 \%)$ using a $\mathrm{MeCN}-\mathrm{H}_{2} \mathrm{O}$ solvent system from 70:30 to $90: 10(\mathrm{v} / \mathrm{v})$ in $20 \mathrm{~min}$ and compound $2(2.1 \mathrm{mg}$, yield $=60 \%)$ using a $\mathrm{MeCN}-\mathrm{H}_{2} \mathrm{O}$ solvent system from 80:20 to $95: 5(\mathrm{v} / \mathrm{v})$ in $25 \mathrm{~min}$, respectively.

\subsection{Cytotoxicity and Apoptosis Assay}

\subsubsection{Materials}

Compounds $\mathbf{1}$ and $\mathbf{2}$ were tested for their cytotoxicity to human MCF-7 and Hela cell lines using the MTT method. Both compounds were dissolved in DMSO at $10 \mathrm{mM}$ and stored at $4^{\circ} \mathrm{C}$. MTT was purchased from Sigma-Aldrich (St. Louis, USA). Rabbit poly-antibody caspase-9, cleaved caspase-3, caspase-3, cleaved PARP, and secondary antibody conjugated horseradish peroxidase were purchased from AB clonal (Wuhan, China). Dulbecco's modified Eagle's medium (DMEM) and fetal bovine serum were obtained from HyClone (Logan, USA). Annexin V-FITC/PI apoptosis detection kit was purchased from Beyotime. (Nanjing, China) All reagents and compounds were analytical grades and commercially available.

\subsubsection{Cell Culture}

Human breast adenocarcinoma cell line (MCF-7) and human cervical carcinoma cell line (Hela) were purchased from Conservation Genetics CAS Kunming Cell Bank. The cells were cultured in high-glucose DMEM with $10 \%$ fetal bovine serum, $100 \mathrm{U} / \mathrm{mL}$ penicillin and $100 \mathrm{mg} / \mathrm{mL}$ streptomycin at $37{ }^{\circ} \mathrm{C}$ under an atmosphere of $5 \% \mathrm{CO}_{2}$.

\subsubsection{Cell Viability Analysis}

Cell viability was assessed by the MTT assay. Cells were plated in 96-well plates at a density of 5000 cells in $200 \mu \mathrm{L}$ of medium per well and incubated $4 \mathrm{~h}$. The cells were treated with different concentrations of $\mathbf{1}$ and 2 for $24 \mathrm{~h}$. At the end of the treatment, MTT solution $(0.5 \mathrm{mg} / \mathrm{mL}$ in DMEM) was added and further incubated for $4 \mathrm{~h}$. The absorbance was subsequently measured at $570 \mathrm{~nm}$. Cell viability was calculated using the following formula: Cell viability $\%=\left(\mathrm{A}_{\mathrm{s}} / \mathrm{A}_{0}\right) \times 100 \% . \mathrm{A}_{\mathrm{s}}$ and $\mathrm{A}_{0}$ are the absorbance of the test substances and control, respectively. $\mathrm{IC}_{50}$ value represents the half of maximal inhibitory concentration.

\subsubsection{Cell Apoptosis Analysis}

MCF-7 cells were planted on 6-well plates and incubated overnight. Next, the cells were treated with different concentrations of 1 for $24 \mathrm{~h}$. For flow cytometry, $1 \times 10^{6}$ cells in $195 \mu \mathrm{L}$ of binding buffer were stained with $5 \mu \mathrm{L}$ of annexin V-FITC and $10 \mu \mathrm{L}$ of PI at room temperature in the dark for 20 min. Cell apoptosis was analyzed using the BD Accuri TM C6 flow cytometer.

\subsubsection{Western Blot Analysis}

MCF-7 cells were lysised with western blotting lysis buffer and $12000 \mathrm{~g}$ centrifugation for $10 \mathrm{~min}$. The protein content of the supernatant was quantified using the BCA assay. Equal amounts of protein were separated on sodium dodecylsulfate polyacrylamide gels (SDS-PAGE) and electroblotted onto polyvinylidene difluoride (PVDF) membranes. Then, the membranes were blocked with blocking buffer (TBST with 5\% skimmed milk) and incubated with primary antibodies overnight at $4{ }^{\circ} \mathrm{C}$. The membranes were washed with TBST and probed with secondary antibodies. Bound immunocomplexes were detected using a ChemiDOC TM XRS + system (Bio-Rad).

\subsubsection{Statistical Analysis}

All experiments were conducted more than three times independently. The results were analyzed by Tukey's range test. The data are given as the mean \pm standard error. $\mathrm{P}$ values $<0.05$ were considered statistically significant.

Acknowledgements This work was financially supported by the National Natural Science Foundation of China (81872762) and the Hubei Provincial Natural Science Foundation of China (2019CFB387). The authors thank the Analytical \& Measuring Center, School of Pharmaceutical Sciences, South-Central University for Nationalities for spectra test.

\section{Compliance with Ethical Standards}

Conflict of interest The authors declare no conflict of interest.

Open Access This article is licensed under a Creative Commons Attribution 4.0 International License, which permits use, sharing, adaptation, distribution and reproduction in any medium or format, as long as you give appropriate credit to the original author(s) and the source, provide a link to the Creative Commons licence, and indicate if changes were made. The images or other third party material in this article are included in the article's Creative Commons licence, unless indicated otherwise in a credit line to the material. If material is not included in the article's Creative Commons licence and your intended use is not 
permitted by statutory regulation or exceeds the permitted use, you will need to obtain permission directly from the copyright holder. To view a copy of this licence, visit http://creativecommons.org/licenses/by/4.0/.

\section{References}

1. F. Bray, J. Ferlay, I. Soerjomataram, R.L. Siegel, L.A. Torre, A. Jemal, CA-Cancer J. Clin. 68, 394-424 (2018)

2. S. Salas-Vega, O. Iliopoulos, E. Mossialos, JAMA Oncol. 3, 382390 (2017)

3. D.J. Newman, G.M. Cragg, J. Nat. Prod. 83, 770-803 (2020)

4. G. F. Bills, J. B. Gloer, 4 (2016). https://doi.org/10.1128/micro biolspec.FUNK-0009-2016.

5. T. Feng, X.Q. Gan, Y.L. Zhao, S.B. Zhang, H.P. Chen, J. He, Y.S. Zheng, H. Sun, R. Huang, Z.H. Li, J.K. Liu, J. Nat. Prod. 82, 45-50 (2019)

6. M. De Bernardi, L. Garlaschelli, G. Gatti, G. Vidari, P. Vita-Finzi, Tetrahedron 44, 235-240 (1988)

7. M. De Bernardi, L. Garlaschelli, L. Toma, G. Vidari, P. Vita-Finzi, Tetrahedron 47, 7109-7116 (1991)

8. D. Gozzini, G.G. Mellerio, G. Gilardoni, M. Clericuzio, G. Vidari, Nat. Prod. Commun. 13, 1097-1100 (2018)

9. S.P.B. Ovenden, J. Yu, J. Bernays, S.S. Wan, L.J. Christophidis, G. Sberna, R.M. Tait, H.G. Wildman, D. Lebeller, D. Platel, T.W. May, B.M. Meurer-Grimes, J. Nat. Prod. 68, 409-412 (2005)
10. X. Yin, T. Feng, J.H. Shang, Y.L. Zhao, F. Wang, Z.H. Li, Z.J. Dong, X.D. Luo, J.K. Liu, Chem. Eur. J. 20, 7001-7009 (2014)

11. T. Feng, J. He, H.L. Ai, R. Huang, Z.H. Li, J.K. Liu, Nat. Prod. Bioprospect. 5, 205-208 (2015)

12. Z.Z. Zhao, H.P. Chen, B. Wu, L. Zhang, Z.H. Li, T. Feng, J.K. Liu, J. Org. Chem. 82, 7974-7979 (2017)

13. S.B. Zhang, Z.H. Li, M. Stadler, H.P. Chen, Y. Huang, X.Q. Gan, T. Feng, J.K. Liu, Phytochemistry 152, 105-112 (2018)

14. F.L. Zhang, H.X. Yang, X. Wu, J.Y. Li, S.Q. Wang, J. He, Z.H. Li, T. Feng, J.K. Liu, Phytochemistry 177, 112431 (2020)

15. G. Ciriello, M.L. Gatza, A.H. Beck, M.D. Wilkerson, S.K. Rhie, A. Pastore, H. Zhang, M. McLellan, C. Yau, C. Kandoth, R. Bowlby, H. Shen, S. Hayat, R. Fieldhouse, S.C. Lester, G.M.K. Tse, R.E. Factor, L.C. Collins, K.H. Allison, Y.-Y. Chen, K. Jensen, N.B. Johnson, S. Oesterreich, G.B. Mills, A.D. Cherniack, G. Robertson, C. Benz, C. Sander, P.W. Laird, K.A. Hoadley, T.A. King, TCGA Research Network, C.M. Perou, Cell 163, 506-519 (2015)

16. E. Panza, M. Tersigni, M. Iorizzi, F. Zollo, S. De Marino, C. Festa, M. Napolitano, G. Castello, A. Ialenti, A. Ianaro, J. Nat. Prod. 74, 228-233 (2011)

17. D. Green, G. Kroemer, Trends Cell Biol. 8, 267-271 (1998) 